\title{
Study on College Students' Orderly Political Participation from the Perspective of Socialist Democratic Politics
}

\author{
Yu He, Wenkuan Chen \\ Sichuan Agricultural University, Chengdu, Sichuan, 611130
}

Keywords: Socialist Democratic Politics; College Students; Orderly Political Participation

\begin{abstract}
It is an important subject to strengthen and improve the ideological and political work of college students in the new situation. It is also the basic project of the construction of socialist democratic politics with Chinese characteristics. The concept and ability of their orderly political participation are influenced by the times and society. , Education and the characteristics of their own development and other factors. It is of great significance to study how these factors affect the political participation of contemporary college students, to guide students to participate in orderly behavior, to cultivate orderly participation in the main body and promote social stability and harmonious development
\end{abstract}

\section{Introduction}

To strengthen the study and cultivation of students' orderly political participation is an important subject of ideological and political work in colleges and universities, and also a basic project for the construction of democratic politics in our country. The 18th National Congress of the Communist Party of China pointed out that "expanding the orderly political participation of citizens from various fields and levels is the main way to realize the political rights of citizens. It is the major task and basic content of the construction of socialist democratic politics with Chinese characteristics and the well- Give Full Play to the Important Embodiment of the Superiority of the Socialist Political System. As an outstanding representative among the youth groups, college students are the reserve army and the backbone of the development and construction of socialist democratic politics. It is necessary to carry out political participation in order to carry out political participation.

Then request. The development of socialist democratic politics and the construction of socialist political civilization are important targets for the construction of socialist modernization. College students, as outstanding representatives of youth groups, are the reserve forces and the backbone of the development and construction of socialist democratic politics. It is a basic project to build a socialist political civilization to strengthen the cultivation and guidance of the orderly political participation of college students.

\section{The Meaning of College Students Political Participation}

The orderly political participation of college students is an important part of the composition of Chinese democratic politics. The main activities of college students are schools. Students participate in the daily management of schools by joining the League branch, the party branch, joining the community, the student union and the class cadre. Students participate in political activities that are directly related to their own interests through class democratically elected elections, participation in social meetings, etc., directly involved in social practice. In the special period, college students' attempts to use their own speech and action indirectly affect the political participation of the national policy by means of meditation, procession, demonstration and so on. Understand the meaning of political participation of college students in order to understand the types of political participation of college students: the different roles of active participation, passive participation and 
passive participation on participation results can be used to guide contemporary college students to achieve the best political participation with optimal participation result. Different forms of political participation: voting, election, association, petition, etc. to apply different social environment and events, which to analyze what kind of participation can play the greatest impact.

\section{The Contemporary University Students Political Participation in the Performance Characteristics}

Whether the political system is sound and directly affects the frequency and state of the radical social activities. China's legal system is not yet sound, to the people to express their views of the channel is not enough, democracy and legal awareness has not been deeply rooted in the whole society. In the past student movement, the active participation in national events but showing a blood and blind, with a high political and cultural literacy but lack of reason and so on. This is not only with the students at this stage of the psychological and physiological changes in the characteristics, but also closely related with the changing times. In today's self-interest as the center of the political participation in the political participation of college students in the social, family, school, cultural heritage and exchanges under the emergence of many characteristics of the times with the characteristics of the times.

Political participation in the passion and immature legal system construction and supervision of the formation of contradictions. Contemporary college students more contact with the network media, in the network to participate in political enthusiasm. However, because college students in the student status of the transition to the special period of society, its outlook on life, values are relatively unstable. Foreign use of the network to convey a capitalist faculties of college students, leading to many college students have "foreign moon than the Chinese circle," the wrong idea. China has not yet perfect on the political participation of the relevant legal system, has not yet sound social network supervision and supervision. College students use the anonymity of the network, online politics, free to express their views. However, it is this unsupervised disorderly political participation by many college students as vent channels, whether true or not, are fiercely attacked. Although the University has carried out a lot of political science courses, but many of the students are only for the examination and learning, so the political participation of the theoretical quality is relatively low. The development and use of the network Although the students more channels of political participation, but because the political literacy is not high enough, the information

True and false identification of the lack of attitude to the whole society is also more extreme. They are eager to participate in politics, but do not know what kind of impact will be brought about. The law does not prohibit the lack of detailed legislation on political participation and the lack of enforcement of relevant laws, resulting in college students in the political participation can not be fully considered the consequences. Leading to disorderly political participation to the community caused a greater negative energy.

Political utilitarian prominent, political consciousness and behavior contrary. Under the influence of the market economy tide, everyone "to the money to see", college students also have a strong individualism. Therefore, the first thing students want to participate in any event is whether they are beneficial. However, in the special cultural background of the lack of channels for the adoption of public opinion in China, college students can not feel the most direct benefit of their political participation, so they will lead to the lack of political participation of college students. And for some of the student-related management of the school's political activities, students hold for their own interests and strive for pure utilitarian purposes, one-sided consideration of their own interests and participation, this impetus is very likely to lead to unfair The

As a group of passion and ideals, college students hate the phenomenon of social corruption and injustice, in the face of corrupt officials and anti-corruption related news, it is excitement. However, in their own actual performance with the contrary, hate bad faith behavior, but it will not seriously study the face of the examination to take cheating, get the skills to buy the answer to the certificate. On the so-called "relationship households" that extreme despise, but when they need to find a way 
to "relationship households." The school evaluation awards unfair dissatisfaction, turn to their own when the students in the group to help send, for the evaluation of awards and a series of vital interests to create unfair environment, their actions can not match with the actual.

The active participation of college students in the initiative has yet to be improved. Some college students have an orderly political participation attitude and even the tendency to indelerate, participate in political activities show no concern, indifference, escape, or even do not want to participate in the attitude. This attitude of the desertification, reflecting the current political life of the mistrust is not conducive to the expression of public opinion, political aspirations can not be met, political participation should be generated by the positive role is difficult to effectively play, and then the development of socialist democratic politics negative influences.

In the orderly political participation activities, the attitude of college students is not strong mainly to participate in political life is not interested in, and even some college students to political participation as a task and command, passive implementation, attitude indifference. Some college students believe that politics is a national matter, and their relationship is not so, so "things do not care about the high hanging", expressed indifference to the country's political affairs. These college students are not concerned about the National People's Congress, do not care about the major political events such as the CPPCC, and political topics are rarely mentioned, they are more willing to discuss with the employment, civil servants and other issues related to their own interests. Some college students are not active in the activities of school party organizations, in the collective activities of the performance of indifference. Some students even when they participate in political activities is also showing a passive state, holding the indifferent attitude, follow the trend, with the flow. In the event of voting and other activities, but also to the relationship between pro-and other factors as an election standard, the purpose of the election more casual and blind, to express their true thoughts hold indifferent attitude.

Some college students are more concerned about some political issues in the process of their political participation, but they are not enthusiastic about the real participation of political activities. In other words, some college students are more willing to pay attention to through some media to pay attention to political events, rather than directly involved in political activities, the actual political participation attitude is not active.

In the process of orderly political participation, the indifference of college students' attitude is not conducive to the reasonable expression of political opinions, which is not conducive to the timely detection and effective solution of the problems. Moreover, this negative attitude is easy to produce the country and the government's work is not concerned about, do not participate in the formation of the separation of the state and the masses, in a certain contradiction intensified, it is easy to lead to difficulties in consultation and communication, resulting in irrational politics Participate in behavior, undermine social stability, affect the development of China's socialist democratic politics.

Education and management model is flawed. The way of education in colleges and universities is in the process of reform and transformation. The old single education mode has been difficult to meet the development needs of college students. The traditional educational methods cultivate students lack the ability of innovation and practical ability, which also becomes the students in political participation Of the actual driving force of the important reasons. In addition, in the school management model, the degree of attention to the status of students is not enough, not fully into the school management and decision-making system, in the collection of opinions and information disclosure, although there is a certain upgrade, but there are some shortcomings, such as In the student congress of the convening of the work and other meticulous management has yet to be further improved.

\section{The Way of Contemporary Students to Orderly Political Participation}

To cultivate the correct political view of college students. The realization of democratic politics, requires the people to establish a democratic consciousness. Whether college students can correctly grasp the law of social development and establish the correct sense of political participation is the 
social, school, family and so on the impact of students and students to improve the quality of the common results. The political system of the country, the strong political participation atmosphere of the school, the active discussion of the political topic in the family as the external conditions of the life of college students, has a positive effect on the cultivation of its own political consciousness. Improve the political quality of students, from the inside out to show a positive political participation play a more role in promoting.

The reason why college students can not be conscious of their own actions and unity, rationality can not overcome the rational, the most important reason is not to establish the correct guiding ideology, not adhere to the theory and practice. College students lack of political participation skills, but also because the theoretical knowledge is not solid enough. As a family, cultivating healthy, honest and independent personality is the foundation of college students as a qualified citizen. School is the most important place for college students to grow, the university environment and education will play the most critical role for college students. Schools should continue to promote ideological and political education, and guide students to take the initiative to improve their own political participation. Combined with the actual, to encourage students to participate in political activities, the use of holidays, to carry out "three to the countryside", "Western support education" and other activities test theory, rich knowledge, armed with scientific development concept. Social good political atmosphere is able to subtle influence on the life of college students and values. Healthy social atmosphere can make college students correct thinking. And finally establish a correct view of politics.

Broaden the norms of political participation channels, attention to student political participation. First of all, to further improve the democratic management of college students and management system. In addition to the election activities of the deputies to the district (county) people's deputies, the form of democratic management activities directly involved in college students are usually: election activities and management activities of the school Communist Youth League, student union at all levels, student associations, classes and so on. Activities, principals mailboxes, opinions and suggestions collection and other activities with the university managers, the students themselves to discuss and develop part of the system activities. Colleges and universities should continue to improve and perfect these democratic management system and form, at the same time on the basis of formal innovation, such as holding dinner with the principal, etc., to increase the affinity and attractiveness of democratic management.

Second, carry out practical education activities related to democratic management. The school should organize students as much as possible to participate in social welfare activities and practice research activities to enhance the political awareness and political participation of college students, so that students in the process of practical activities to experience the service of others, to serve the community and solve some social problems of responsibility And a sense of accomplishment, and gradually form a good political participation habits.

Again, improve the various groups of assessment agencies evaluation mechanism, play an exemplary role of outstanding students. Party organizations at all levels can take advantage of the high enthusiasm of college students to join the party, in college students in the theory of political participation and practice of education. Colleges and universities should constantly improve the college students to join the party assessment and management methods, the formation of a healthy competition system and selection platform, in all kinds of party organizations in the evaluation of the evaluation should also be based on open, fair and just principles, elected teachers and students recognized , In the students play a good role in the role of outstanding students, and as a typical, through the radio station, publicity column, campus network and other media forms of publicity, in the majority of students to form a strong value recognition and psychological identity to promote The Effective Development of Political Participation Education.

Improve the Feedback Mechanism of Interest Expression. First of all, the relevant government departments should strive to improve the feedback mechanism through e-government. In addition to the traditional public information through the Internet, some of the administrative interests closely related to the people's livelihood should actively open the government 
microblogging, strengthen and improve their own feedback mechanism. College students are the main users of microblogging, they often log microblogging, refresh microblogging, published their own political attitudes and opinions. They are often concerned with social issues that are closely related to their own interests. For example, students are concerned about the criteria for raising the standard of living, the advice on school curricula, the ease of graduation, the difficulty of employment and so on. They will use microblogging to express Their own interests and interests, hope that the relevant departments of society can pay attention to and solve. Government microblogging is to return to the rights and interests of college students in a timely manner to give students a positive and comprehensive feedback to enhance the confidence of college students and the government to improve the political participation of college students confidence.

Second, the news media should strengthen the supervision and feedback work, play the media exposure function. Society should make full use of the media "magnifying glass" function, tracking the development of the reported events, the adverse feedback of the government departments, praise feedback timely departments to enhance the administrative department of self-supervision and self-restraint ability to the political participation of college students to provide a strong Of public opinion.

Again, improve the laws and regulations, refine the feedback mechanism in the law of the obligations and responsibilities. Although the legal mechanism for the political participation of citizens in China is legally stipulated, there is no clear stipulation of the responsibility for the lack of timely and effective feedback. Therefore, the current China should promptly improve the administrative and legislative aspects of the relevant work, a clear government administrative obligations, the establishment of accountability mechanisms to the legal coercive force to protect the effectiveness of students' orderly political participation.

\section{References}

[1] Deng Xiaoping's anthology, Volume 3 [M]. Beijing: People's Publishing House, 1993.

[2] Introduction to political science [M]. Beijing: Higher Education Press, People's Publishing House, 2011.

[3] Feng Jun, Wang Haibo, Ding Zhenjun. From the constitutional perspective of the connotation of civic awareness [N]. People's Daily, 2008-03-26 (7).

[4] Huang Da. The significance of the socialist civic consciousness [N]. Guangming Daily, 2001-11-27 (B01).

[5] Wang Yan. College students network political participation in the dilemma [J] .Chinese Youth Research, 2014, (2). 